Association for Information Systems AIS Electronic Library (AISeL)

2008

\title{
The Moderating Role of Customer-Technology Contact on Attitude Towards Technology-Based Services
}

Aristeidis Theotokis

Athens University of Economics and Business (AUEB), a.theotokis@aueb.gr

PVlachos

Katherine C. Pramataris

Athens University of Economics and Business (AUEB), k.pramatari@aueb.gr

Follow this and additional works at: http://aisel.aisnet.org/ecis2008

\section{Recommended Citation}

Theotokis, Aristeidis; Vlachos, P; and Pramataris, Katherine C., "The Moderating Role of Customer-Technology Contact on Attitude Towards Technology-Based Services" (2008). ECIS 2008 Proceedings. 62.

http://aisel.aisnet.org/ecis2008/62

This material is brought to you by the European Conference on Information Systems (ECIS) at AIS Electronic Library (AISeL). It has been accepted for inclusion in ECIS 2008 Proceedings by an authorized administrator of AIS Electronic Library (AISeL). For more information, please contact elibrary@aisnet.org. 


\title{
THE MODERATING ROLE OF CUSTOMER-TECHNOLOGY CONTACT ON ATTITUDE TOWARDS TECHNOLOGY-BASED SERVICES
}

\begin{abstract}
Previous studies in information systems research and service marketing treat customer behavior towards technology-based services homogeneously. However, recent studies recognize that users have different attitude towards different technologies even if these technologies used to support the same service. Drawing on literature from service marketing (i.e. customer contact theory), information systems, (unified theory of technology acceptance) and organizational behavior (task complexity theory), this study proposes a construct that classifies technology-based services according to the level of customer-technology interaction they require, namely the Customer-Technology Contact. The moderating effect of this construct on the relationship between individual characteristics -i.e. technology readiness- and attitude towards technology-based services is examined through an empirical study. Technology-based retail services scenarios, with different levels of technology contact, are presented to supermarket shoppers $(n=600)$. Results show that customer technology contact, as a unique service attribute, moderates the effect of personality traits to customers' attitude. The current study introduces this new service attribute that is applicable to ubiquitous computing services, application and design.
\end{abstract}

Keywords: technology-based services, ubiquitous computing, customer contact, consumer behaviour 


\section{INTRODUCTION}

The appearance of new technologies, such as Radio Frequency Identification (RFID), mobile computing, GPS tracking and smart cards provide retailers with a great opportunity to offer innovative customer services (Burke, 2002). The retail services that employ the technology are referred in the literature as technology-based services (TBS) or self-service technologies (SST). It is widely accepted that the introduction of technology in services alters the way that the customer interacts with the information systems and service provider (Bitner et al., 2000; Bobbitt et al., 2001; Dabholkar et al., 2002; Meuter et al., 2005; Meuter et al., 2000). For this reason, researchers have studied technology infusion in service encounters from many different perspectives (Bitner et al., 2000; Bobbitt et al., 2001; Burke, 2002; Childers et al., 2001; Curran et al., 2003; Dabholkar et al., 2002; Froehle et al., 2004; Meuter et al., 2005). While some classification approaches for technology-based services have been proposed (Bitner et al., 2000; Froehle et al., 2004; Meuter et al., 2000; Wemmerlov, 1990), most researchers explore customer attitude and adoption of different technology-based services homogeneously.

Nevertheless, technology-based service delivery has different forms and different technologies may be used by customers even for the same service. Moreover, even if the same technology is used customers interact with it in different levels during each different service procedure. For example, a form of technology-based service is an LCD display that informs customers about promotions in a supermarket store and it requires from the customer to interact with technology by just watching the display. On the other hand, another example of TBS is the self-checkout service which requires from the customer to use a barcode reader technology and -possibly a touch screen for paying. Consequently, technology-based services differ in terms of customer-technology interaction they require and may be misleading to study these two services as a single type of services. Furthermore, other researchers have demonstrated that consumers can have distinguishable attitudes toward different technology-based services (Curran et al., 2005; Curran et al., 2003).

Theoretically rooted in literature from operations management, services marketing and information systems this manuscript describes and theoretically defines the concept of customer-technology contact (CTC). Customer-technology contact refers to the level of interaction with technology that a service requires from the customer in order to be produced. Based on service contact theory (Chase, 1981), on Woods' (1986) framework about task complexity and on the media richness theory postulated by Daft and Lengel (1986), we define CTC as a function of three dimensions: time of interaction with technology, information richness and IT/media sophistication. CTC is an important construct for evaluating and classifying ubiquitous computing services.

It is hypothesized that the level of customer-technology contact as a unique service attribute is important to understand the relationship between user individual characteristics and attitude towards ubiquitous computing services. Current study employs the scenario and survey methodology (Dabholkar et al., 2002), and tests its hypotheses using empirical data from 600 retail customers. Consumers are being presented with two groups of six different services with different customertechnology contact. Individuals' technology readiness is tested as an antecedent of customer attitude towards these services. Customer technology contact is proposed as a moderating factor of the above relationship.

Findings provide evidence that the concept of customer-technology contact, as a unique service attribute, plays an important role in customer adoption of ubiquitous technology. Taken into account the increasing development of ubiquitous computing, this study can provide useful insights for innovative services evaluation and design. 


\section{LITERATURE REVIEW AND HYPOTHESES DEVELOPMENT}

\subsection{Innovative Retail Services and Technology Readiness}

Technology is a major enabler for today innovative retail services (Burke, 2002). Handheld and wireless devices touch screen kiosks, electronic signage and shelf labels, virtual reality displays, body scanning, smart cards, and even robotics or the rapidly forthcoming RFID technologies are some examples of the technologies used in-store in order to enhance shopping experience. Customer acceptance is considered to be a focal theme for the application of new technologies in retail services. The information systems literature provides insights on the user acceptance of technology (Davis et al., 1989; Rogers, 1995; Venkatesh et al., 2003) while service marketing researchers study customer attitude towards self-service technologies. In a nutshell, individual personality characteristics (Bobbitt et al., 2001;Dabholkar et al., 2003; Meuter et al., 2005; Meuter et al., 2003; Meuter et al., 2000; Parasuraman, 2000; Simon et al., 2007; Zeithaml et al., 1987), innovation and technology characteristics (Curran et al., 2005; Curran et al., 2003; Im et al., 2007; Meuter et al., 2005; Simon et al., 2007) or situational factors (Dabholkar, 1996; Dabholkar et al., 2002) have been proposed as antecedent factors that affect customer perceptions about technology-based service delivery.

Among the most significant individual factors postulated as affecting customer perceptions about technology-based services is technology readiness (Tsikriktsis, 2004). Parasuraman (2000, p.308) proposes technology readiness as a personality trait that is referred to: "the people's propensity to embrace and use new technologies for accomplishing goals in home life and at work". Technology readiness is a concept that actually helps both academics and managers to understand the distinctive behavioural process behind the adoption of technology-based products and services. According to Parasuraman (2000), technology readiness can be categorized into four distinct components: optimism, innovativeness, discomfort, and insecurity.

Based on the aforementioned review of the literature, we formulate the study's hypotheses:

H1. TR is related to customer's attitude towards technology-based retail services, and more specifically:

H1a. The dimension of optimism and innovativeness of TR are positively related to customer attitudes toward technology-based retail services

H1b. The dimension of discomfort and insecurity of TR are negatively related to customer attitudes toward technology-based retail services

\subsection{The concept of Customer-Technology Contact (CTC)}

Drawing on the customer contact theory, we describe and theoretically define the concept of Customer-Technology Contact (CTC). Conceptually, the theory of customer contact investigates the level of customer interaction with the service provider or the service system. In parallel to this theory, we propose a concept that represents the level of customer-technology interaction in a service delivery system and propose a classification of low and high customer-technology contact services. Unlike operation management researchers - who study the customer contact concept in order to explain operational efficiencies - this study views this concept from the consumer perspective and proposes this classification in order to examine customer attitude towards retail technology-based services. Customer-technology contact is applicable in all service modes where the customer interacts directly with the technology in order to produce the service. Figure 1 depicts the concept of customertechnology contact versus the notion of customer-service provider contact in a technology-based service setting. 


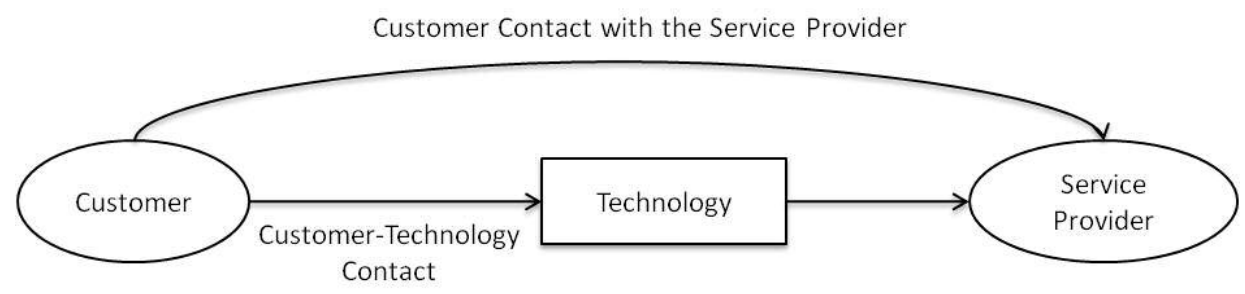

Figure 1. The concept of customer - technology contact

Customer-Technology Contact is a specific service characteristic and is referred to the customertechnology interaction level during the service process. Customer-technology contact, actually, describes how demanding a service is in terms of technology interaction from the consumer perspective and categorizes technology-based services into low and high technology-contact services. For example, an in-store LCD display informing customers about promotions can be considered as a low technology-contact service while a self-checkout system is a high technology-contact service, because the former requires that the consumer interacts with the technology much less than the latter.

The CTC concept is somehow relevant to the concept of technology visibility that has its roots in the pervasive IS literature (Birnbaum, 1997; Satyanarayanan, 2001). Thus, customer-technology contact does not account for the technology that is used by the service application or by the service representative in the background - and therefore is unobservable by the customer. CTC is referred to the amount and type of interface technology that is used by the customer in order to get the serviceand is therefore observable.

Although, the time of interaction is the factor most usually considered when operationalizing the customer contact with a service system in the customer contact theory, the CTC notion takes into account two additional dimensions: the IT/media sophistication and the level of interactivity or information richness. Therefore, while during automated phone ordering the customer may spend more time interacting with the phone technology by pressing numbers, ordering through an interactive television is a higher technology-contact service because the customer needs to interact with a more complex technology (Bobbitt et al., 2001). Table 1 presents the dimensions of the proposed construct of customer-technology contact and the relevant supporting theories used to build it.

\begin{tabular}{|l|l|l|}
\hline Dimension & Definition & Relevant Constructs / Theories \\
\hline $\begin{array}{l}\text { Time of Interaction } \\
\text { with Technology }\end{array}$ & $\begin{array}{l}\text { The time (or the number of distinct steps) that a user } \\
\text { interacts with technology during the service process }\end{array}$ & $\begin{array}{l}\text { Time of Contact (Chase, 1981; Chase et } \\
\text { al., 1983; Kellogg et al., 1995) } \\
\text { Component complexity(Nadkarni et al., } \\
\text { 2007; Wood, 1986) }\end{array}$ \\
\hline Information Richness & $\begin{array}{l}\text { The amount and the directionality of information } \\
\text { cues that a the user must process during the service } \\
\text { process }\end{array}$ & $\begin{array}{l}\text { Information Richness (Daft et al., 1986) } \\
\text { Coordinative Complexity (Nadkarni et } \\
\text { al., 2007; Wood, 1986) }\end{array}$ \\
\hline $\begin{array}{l}\text { IT/Media } \\
\text { sophistication }\end{array}$ & $\begin{array}{l}\text { The level of sophistication and complexity of the IT } \\
\text { and interface used during the service process }\end{array}$ & $\begin{array}{l}\text { Dynamic Complexity (Nadkarni et al., } \\
\text { 2007; Wood, 1986) } \\
\text { Level of intimacy (Kellogg et al., 1995) }\end{array}$ \\
\hline
\end{tabular}

Table 1. Customer-Technology Contact dimensions and supporting theories 


\section{THEORETICAL MODEL}

Exploiting the concept of customer technology contact, the present study proposes a theoretical model for studying customer attitude towards technology-based retail services. In this section, we formulate our hypotheses concerning consumer behaviour by integrating theories from innovation and technology acceptance such as Diffusion of Innovations (Rogers, 1995), Technology Acceptance Model (Davis et al., 1989) and the Unified Theory of Acceptance and Use of Technology (Venkatesh et al., 2003).

The diffusion of innovations theory (Rogers, 1995, p.242) postulates that the complexity of an innovation, as perceived by potential adopters, is negatively related to the speed of diffusion of that innovation. Moreover, ease of use, which is opposite to Roger's complexity, is positively correlated to the use of consumer technologies, such as computer software. Venkatesh et al. (2003) in the Unified theory of acceptance and use of technology (UTAUT) define the construct of effort expectancy as the degree of ease associated with the use of the system and find negative association with behavioural intentions of using the technology. These theories underline that the more the consumer perceives a technology-based service innovation as difficult to use, the less likely he or she is to have a positive attitude towards the innovation.

In parallel, recent research efforts have demonstrated that attitudes toward different technologies used for the delivery of the same service will be separate and distinct from one another (Curran et al., 2005). Furthermore, several researchers have empirically supported that the type of technology that a specific service uses affects customer attitude and usage of technology-based services (Curran et al., 2005; Curran et al., 2003; Im et al., 2007). Furthermore, Heijden (2004) argue that user acceptance of hedonic technologies has different antecedent predictors than utilitarian technologies. Based on the proposed concept of customer-technology contact, we assume that different technologies supporting the same service differentiate it in terms of customer-technology interaction.

Therefore, customer-technology contact as a service characteristic is expected to have a moderating effect on the technology readiness - attitude relationship. Specifically, for low customer-technology contact services the influence of technology readiness may be attenuated since consumers do not anticipate high levels of technology interaction and thus cognitive effort in order to understand the service offerings and use this service delivery option.

H2. The customer-technology contact (CTC) characteristic of a service moderates the effect that technology readiness (TR) has on customer attitude towards the service and specifically:

H2 (a). For services with higher CTC the effect of TR on attitude will be strengthened.

H2 (b). For services with lower CTC the effect of TR on attitude will be attenuated.

Figure 2 shows the conceptual model of the present study. The four dimensions of TR are assumed to influence customer attitude towards technology-based services. But, this effect is hypothesized to be moderated by the customer-technology contact of a service.

\section{METHODOLOGY}

Then, using a selection process we choose six technology-based services that can be classified into two groups according to their customer-technology contact. The next step was the data collection. We collected data in ten stores of five grocery retail chains in Western Europe. Using the scenario and 
survey methodology (Dabholkar \& Bagozzi, 2002) and a sample of 603 customers, we measured customer attitudes towards innovative retail service concepts and technology readiness. The next sections present each step of the methodology in more detail.

\subsection{Data Collection and Sample}

This empirical research was based on a sample of supermarket shoppers who are the main candidate users of retail services. Nine research associates were simultaneously occupied in data collection in ten supermarket stores in Greece for 2 weeks. Data were collected during a in different time slots so as to ensure a representative cross-section of shoppers. During the data collection procedure, researchers were approaching customers asking them to participate in a research that is conducted by the university. The trained research associates were initially spending some time to present each of the six service concepts to the surveyed customer and to answer possible customer questions. After the description of each service concept, respondents were filling-in the relevant section of the questionnaire. All respondents were presented with all the six service scenarios.

The interviewers contacted 2,100 people of which 631 agreed to participate in the survey. Twentyeight responses were inappropriate for analysis, leaving a sample of 603 responses and a response rate of $30 \%$. Data were collected using a proportionate stratifying sampling technique and the sample was representative of Greek supermarket shoppers, as indicated by retail mangers of the six supermarket chains. Overall, $69 \%$ of the respondents were women. In terms of age group representation, the sample was balanced. Almost half of the respondents were in the 25-44 age group (51\%) and approximately one out of three was in the +44 age group ( $24 \%$ in the $44-55$ age group and $10 \%$ in the +55 group). Finally, $15 \%$ of the sample belonged to the $18-25$ age group.

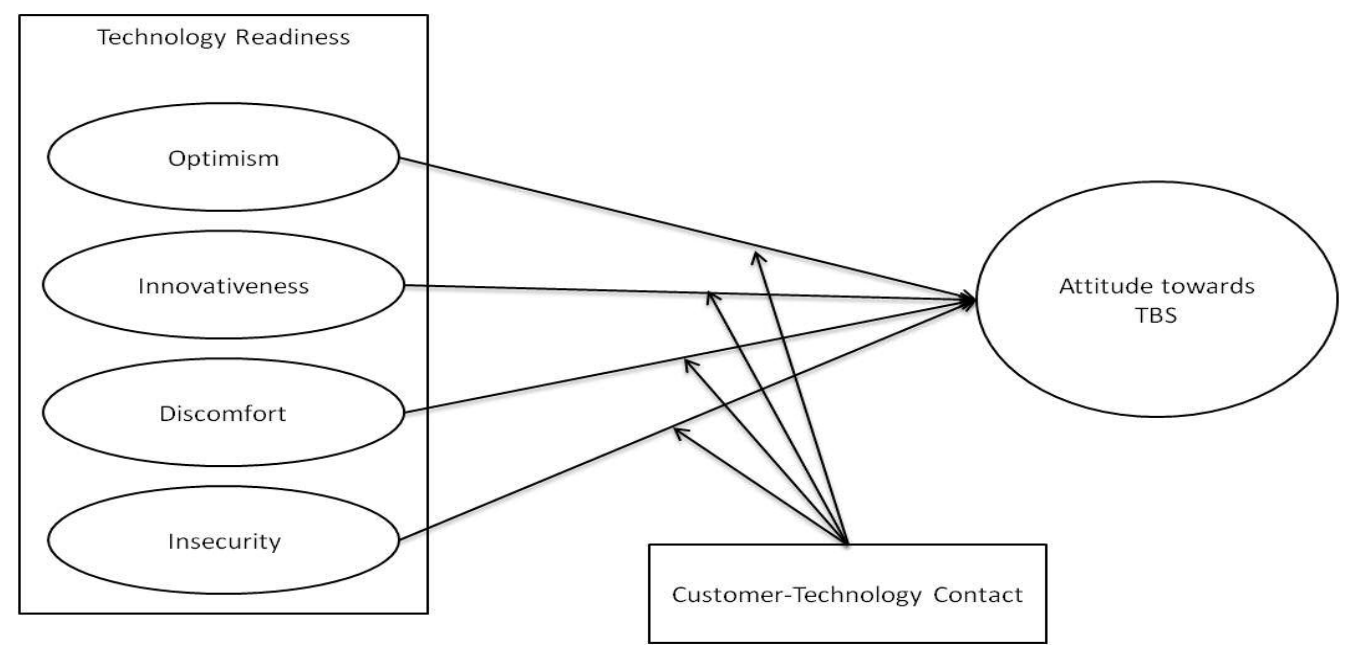

Figure 2. The research model

\subsection{Measures}

Attitude was measured using 9-point semantic-differential scales, with the words extremely, quite, slightly, and neither below the scales to mark each point (Fishbein et al., 1975). A four-item scale with the endpoints good-bad, like-dislike, pleasant-unpleasant and likely-unlikely-to-use was used to measure attitude towards service usage. After describing each concept interviewers asked respondents to rate on a nine-point scale how well they had understood the service concept (Dabholkar and 
Bagozzi (2002). Taking into account time constraints and in order to avoid respondent fatigue, not all 36 TR items proposed by Parasuraman (2000) were included in the questionnaire Instead, the abbreviated scale of TR as suggested by Parasuraman and Colby (2001) was used adjusted for the retail context. The translations were performed by native speakers and were back translated to remove and reduce any translation errors.

\section{RESULTS}

In estimating and testing the proposed theoretical model we followed the two-step procedure suggested by Anderson and Gerbing (1988), employing the structural equation modelling analytical framework. Due to multivariate non-normality, the study uses the bootstrap method in order to estimate the standard errors of the model parameter estimates. Six different models, one for each service concept, were tested (see figure 3). Moreover, because we drew on dimensions of CTC from different research areas, a first exploratory phase was important to ensure that the classification of our six service concepts as high and low technology contact services was consistent valid.
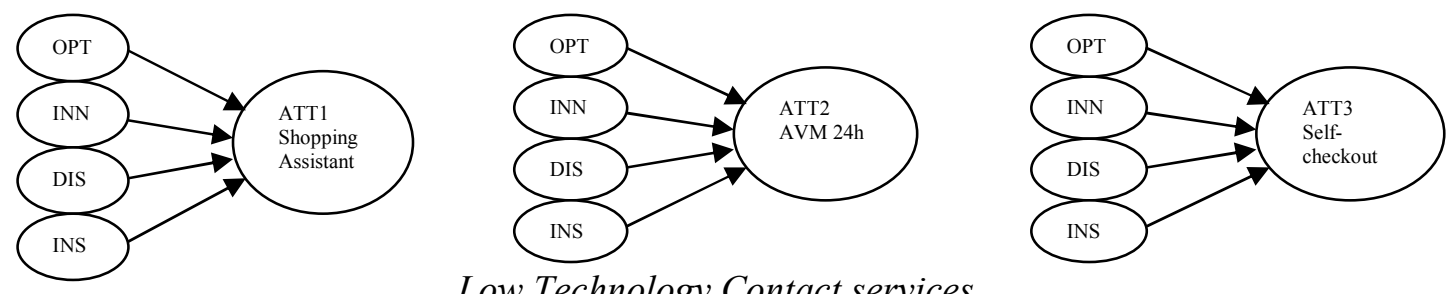

Low Technology Contact services
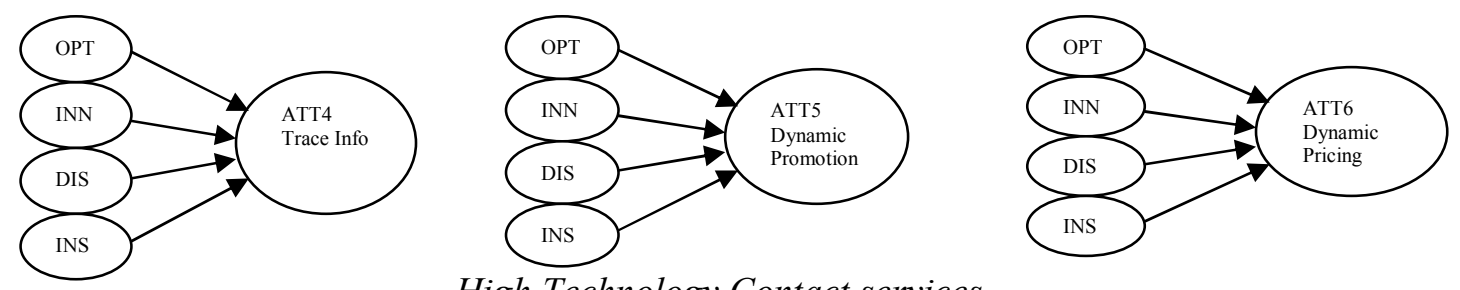

High Technology Contact services

Figure 3. $\quad$ The six different models used in analysis design

\subsection{Classification of Innovative Retail Services}

In order to categorize the defined services according to their level of customer-technology contact, a qualitative exploratory study was conducted based on a convenience sample of retail service experts. Based on the three dimensions described above - time of contact, media richness and level of interactivity- as adapted from the customer contact theory (Kellogg et al., 1995) and adjusted appropriately to the technology context, service experts classified the six service concepts to high and low technology-contact services. Table 2 presents the six service concepts and summarizes their classification using the three dimensions of technology contact. Ratings are considered at the service episode level similar to the theory of customer contact (Kellogg et al., 1995). 


\begin{tabular}{|c|c|c|c|c|c|}
\hline Groups & Service Name & Service Concept Description & $\begin{array}{c}\text { Time of } \\
\text { Contact with } \\
\text { technology } \\
\end{array}$ & $\begin{array}{c}\text { IT/media } \\
\text { Sophistication }\end{array}$ & $\begin{array}{c}\text { Information } \\
\text { Richness/ } \\
\text { Directionality }\end{array}$ \\
\hline \multirow[t]{3}{*}{$\begin{array}{l}\text { High } \\
\text { Technology } \\
\text { Contact } \\
\text { services } \\
\end{array}$} & $\begin{array}{l}\text { Digital } \\
\text { Shopping } \\
\text { Assistant }\end{array}$ & $\begin{array}{l}\text { A touch screen equipped tablet } \\
\text { PC with a UPC scanner affixed } \\
\text { to the shopping cart }\end{array}$ & High & High & 2-ways \\
\hline & $\begin{array}{l}\text { Automatic } \\
\text { Vending } \\
\text { Machine } 24 \mathrm{~h}\end{array}$ & $\begin{array}{l}\text { A vending machine similar to } \\
\text { ATM where customers can buy } \\
\text { basic grocery retail products }\end{array}$ & High & Medium & 2-ways \\
\hline & Self- Checkout & $\begin{array}{l}\text { The customer scans the } \\
\text { products by herself using a } \\
\text { hand or fixed scanner and pays } \\
\text { at electronic cashiers }\end{array}$ & High & High & 2-ways \\
\hline \multirow[t]{3}{*}{$\begin{array}{l}\text { Low } \\
\text { Technology } \\
\text { Contact } \\
\text { services }\end{array}$} & $\begin{array}{l}\text { Traceability } \\
\text { Information }\end{array}$ & $\begin{array}{l}\text { A digital display that provides } \\
\text { information about the history } \\
\text { and quality of food products } \\
\text { (where it has been produced, } \\
\text { how it has been transferred etc. } \\
\text { until reaching the shelf) }\end{array}$ & Medium & Low & 1-way \\
\hline & $\begin{array}{l}\text { Dynamic } \\
\text { Pricing }\end{array}$ & $\begin{array}{l}\text { Electronic price tags that } \\
\text { dynamically change to present } \\
\text { reduced prices of products } \\
\text { according to their situation or } \\
\text { expiry date }\end{array}$ & Low & Low & 1-way \\
\hline & $\begin{array}{l}\text { Personalized } \\
\text { Promotion }\end{array}$ & $\begin{array}{l}\text { Digital displays that inform } \\
\text { customers with personalized } \\
\text { promotions about the product } \\
\text { that was just picked-up from the } \\
\text { shelf. }\end{array}$ & Medium & Low & 1-way \\
\hline
\end{tabular}

Table 2. Classification of the retail services concepts based on Customer-Technology Contact

To ascertain our classification of the six innovative service scenarios, a factor analysis based on customers' attitude was used. Factor scores for the three items of each of the six attitudes were calculated. Then a factor analysis based on this factor scores clearly identified the two underlying factors that were expected. The results of this analysis can be seen in Table 3. The six attitudes loaded on two factors. More specifically Factor 1 reflected the attitudes towards the low-technology contact services and Factor 2 the attitudes towards high-technology contact services. Ninety three percent of the total variance was explained by the two factors.

\begin{tabular}{lll}
\hline Attitude towards* & Factor 1 & Factor 2 \\
\hline Digital shopping assistant &,- 042 & $\mathbf{6 6 5}$ \\
AVM 24h &, 102 & $\mathbf{, 6 9 7}$ \\
Self-Checkout &, 058 & $\mathbf{, 7 8 3}$ \\
Traceability Info & $\mathbf{, 7 3 0}$ &, 146 \\
Dynamic Promotion & $\mathbf{, 8 2 5}$ &, 059 \\
Dynamic Pricing & $\mathbf{, 7 0 4}$ &,- 011 \\
\hline
\end{tabular}

Table 3. $\quad$ Factor analysis for attitudes towards six service concepts 


\subsection{Measurement Model}

We established unidimensionality/consistency, reliability, convergent and discriminant validity employing the confirmatory factor analysis framework (see table 3). We computed AVE, shared variance ( $\gamma$ squared) and composite reliability. The six measurement models fit reasonably well establishing unidimensionality. All estimated loadings of indicators for the underlying constructs are significant and greater than 0, 5. Moreover, Composite Reliability exceeds the .7 threshold for all involved constructs. In addition, the Average Variance Extracted (AVE) is greater than the .50 benchmark (Fornell et al., 1981) establishing convergent validity. The data for the model also suggest discriminant validity, since the square root of AVE exceeds all correlations between constructs.

\subsection{Structural Model}

Building on the above measurement models, we have tested the six structural models. Thus, we have specified six structural models (one for each service) in which attitude has been regressed to the four dimensions of technology readiness. The fit indices of the six structural models are acceptable (RMSEA $<0,06 / \mathrm{CFI}>0,975 / \chi^{2} / \mathrm{df}<2$ ) and all significant at $\mathrm{p}<0.01$. The standardized regression weights are presented in Table 4.

It is clearly evident from the table that technology readiness is related to customers' attitude towards the six innovative retail services. We can thus accept Hypothesis 1. Concerning Hypothesis 2, which states that the effect of TR to attitude is moderated by the level of technology-contact of a service, this can be partly accepted. More specifically, the results indicate that for the first group of services - the three high-technology contact services- the optimism and innovativeness have a positive effect to attitude while discomfort and insecurity have a negative effect. On the other hand, for the second group of services - the three low-technology contact services - optimism has still a positive effect on attitude. Nevertheless, innovativeness has a negative effect, while discomfort and insecurity have no statistically significant effect. Therefore we could say that technology contact moderates the effect of the three (innovativeness, discomfort and insecurity) out of four dimensions of technology readiness.

\begin{tabular}{|c|c|c|c|c|c|}
\hline & Attitude towards services & Optimism & Innovativeness & Discomfort & Insecurity \\
\hline \multirow{4}{*}{$\begin{array}{l}\text { High Technology } \\
\text { Contact }\end{array}$} & Shopping Assistant &, $100 *$ &, $154^{*}$ &,$- 104 *$ &,$- 132 * *$ \\
\hline & AVM 24h &, $113^{*}$ &, $118^{*}$ &,$- 139 *$ &,$- 160 * *$ \\
\hline & Self-checkout &, $289 *$ &, $173 *$ &,$- 205^{*}$ &,$- 160^{*}$ \\
\hline & Trace Info &, $108^{*}$ &,$- 186^{*}$ & n.s*** & n.s*** \\
\hline \multirow{2}{*}{$\begin{array}{l}\text { Low Technology } \\
\text { Contact }\end{array}$} & Dynamic Promotions &, $164 *$ &,$- 240 *$ & n.s $* * *$ & n.s $* * *$ \\
\hline & Dynamic Pricing &, $187 *$ &,$- 170^{*}$ & n.s $* * *$ & n.s $* * *$ \\
\hline
\end{tabular}

Table 4. Standardized regression weights of the dimensions of TR on attitude towards services 


\section{DISCUSSION AND CONCLUSIONS}

The different usage of pervasive technologies in services, actually, alters the level of customertechnology interaction a service requires. This research contributes to the ubiquitous computing and technology based services literature in two ways. Firstly, it has investigated the effects of individuals' technology readiness on attitude towards technology-based retail services. Secondly, it proposes, theoretically defines and empirically tests the concept of customer-technology contact (CTC). Several research efforts from different disciplines propose factors that affect customer attitude towards technology-based services, but most researchers treat this type of service delivery as a homogeneous group. However, findings from this study suggest that technology-based services differ in terms of the level of customer-technology interaction they require. Drawing on several theories from information systems, marketing and operations management, we proposed the concept of customer-technology contact which is a unique service characteristic. Moreover, we showed that the impact of technology readiness on attitude is moderated by the notion of CTC. Three out of the four dimensions of TR have shown different impact on attitude towards low and high technology contact services. Specifically, insecurity and discomfort have had negative impact on attitude towards high technology-contact services and statistically insignificant impact for low technology-contact services. On the other hand, innovativeness was positively associated with attitude towards high technology-contact services but negatively associated with attitude towards low technology-contact services.

The implications of this research for managers are important. Personality characteristics influence attitude towards the use of technology in service encounters. However, customer-technology contact, i.e. the level of customer interaction with the technology that a specific service requires, moderates this effect. In fact, for low technology-contact services, the impact of TR on attitude is eliminated or reversed. It is therefore important for a manager to be aware of this and make the right choices regarding the use of technology when designing a new service system. Managers, through appropriate design could manipulate this specific service characteristic and improve customer attitude and adoption. For instance, the usage of different technology for providing to customer the same service could change the technology contact of it. Take for example the self-checkout service, if RFID technology is used, the technology contact that is required from the customer will be much less than if UPC scanners are used. In the first case, customer would just pass-through his trolley and automatically all products would be scanned, while in the second case customer has to scan each product separately. Therefore, the time and the level that customer interacts with technology in these two cases is quite different and therefore the level of technology contact. Of course, financial and other managerial aspects when designing a service system should be considered for ensuring its success.

This study had several limitations but these limitations offer opportunities for further research. Firstly, customer technology contact could be operationalized as a latent (non-observable) variable that would measure customer perceptions about the level of interaction with technology that a service requires namely perceived technology contact. However, before constructing an empirically derived measure for a concept, it is necessary to theoretically define it and provide an empirical proof of its value, which was the purpose of this paper. Moreover, this study examined only a limited set of constructs, which is small considering the variety of those studied in other researches and as a result a small amount of the variance of attitude was explained. However, the scope of this research was to propose a classification concept for technology-based service rather than explore the antecedent factors of attitude towards them. It would also be desirable to include the full 36-item TR scale to enhance the reliability and validity of the TR measure.

Future research could follow two main directions. Firstly, exploiting psychometric scaling techniques or another construct development methodology we could provide an empirically derived measurement model for perceived customer-technology contact. On the other hand, we could explore the same technology-based service scenario but with different interfaces and technologies that manipulate the 
technology contact of the service. The effect of individuals' familiarity with technology (i.e. technology anxiety) and perceived customer-technology contact of services could be tested as antecedents of customers' perception about services based on technology acceptance theories (i.e. performance expectancy and effort expectancy).

\section{REFERENCES}

Anderson, J. C. and Gerbing, D. W. (1988) Structural Equation Modeling in Practice: A Review and Recommended Two-Step Approach, Psychological Bulletin, 103 (3), pp. 411-423.

Birnbaum, J. (1997) Pervasive information systems, Communications of the ACM, 40 (2), pp. 40-41.

Bitner, M. j., Brown, S. and Meuter, M. (2000) Technology infusion in service encounters, Journal of the Academy of Marketing Science,, 28 (1), pp. 138-149.

Bobbitt, L. M. and Dabholkar, P. A. (2001) Integrating attitudinal theories to understand and predict use of technology-based self-service, International Journal of Service Industry Management, 12 (5), pp. 423-450.

Burke, R. (2002) Technology and the Customer Interface: What Consumers Want in the Physical and Virtual Store, Journal of the academy of Marketing Science, 30 (4), pp. 411-432.

Chase, R. (1981) The Customer Contact Approach to Services: Theoretical Bases and Practical Extensions, Operations Research, 29 (4), pp. 698-706.

Chase, R. and Tansik, D. (1983) The Customer Contact Model for Organization Design, Management Science, 29 (9), pp. 1037-1050.

Childers, T. L., Carr, C. L., Peck, J. and Carson, S. (2001) Hedonic and utilitarian motivations for online retail shopping behavior, Journal of Retailing, 77 pp. 511-535.

Curran, J. and Meuter, M. (2005) Self-service technology adoption: comparing three technologies, Journal of Services Marketing, 19 (2), pp. 103-113.

Curran, J., Meuter, M. and Suprenant, C. (2003) Intentions to Use Self-Service Technologies: A Confluence of Multiple Attitudes, Journal of Service Research, 5 (3), pp. 209-224.

Dabholkar, P. A. (1996) Consumer evaluations of new technology-based self-service options: An investigation of alternative models of service quality, International Journal of Research in Marketing, 13 29-51.

Dabholkar, P. A. and Bagozzi, R. (2002) An Attitudinal Model of Technology-Based Self-Service: Moderating Effects of Consumer Traits and Situational Factors, Journal of the Academy of Marketing Science, 30 (3), pp. 184-201.

Dabholkar, P. A., Bobbit, L. M. and Lee, E. J. (2003) Understanding consumer motivation and behavior related to self-scanning in retailing International Journal of Service Industry Management, 14 (1), pp. 59-95.

Daft, R. L. and Lengel, R. H. (1986) Organizational Information Requirements, Media Richness and Structural Design, Management Science, 32 (5), pp. 554-571.

Davis, F. D., Bagozzi, R. P. and Warshaw, P. R. (1989) User Acceptance of Computer Technology : a comparison of two theoretical models, Management Science, 35 (8), pp. 982-1003.

Fishbein, M. and Ajzen, I. (1975) Belief, Attitude, Intention, and Behavior: An Introduction to Theory and Research. , Addison-Wesley, Reading MA.

Fornell, C. and Larcker, D. F. (1981) Evaluating Structural Equation Models with Unobservable Variables and Measurement Error, Journal of Marketing Research, 18 (1), pp. 39-50.

Froehle, C. and Roth, A. (2004) New measurement scales for evaluating perceptions of the technology-mediated customer service experience, Journal of Operations Management, 22 121. 
Heijden, H. V.D. (2004) User Acceptance of Hedonic Information Systems, MIS Quarterly, 28 (4), pp. 695-704.

Im, I., Kim, Y. and Han, H.-J. (2007) The effects of perceived risk and technology type on users' acceptance of technologies, Information \& Management, In Press, Corrected Proof.

Kellogg, D. and Chase, R. (1995) Constructing an Empirically Derived Measure for Customer Contact, Management Science, 41 (11), pp. 1734-1749.

Meuter, M., Bitner, M., Ostrom, A. and S.Brown (2005) Choosing Among Alternative Service Delivery Modes: An Investigation of Customer Trial of Self-Service Technologies, Journal of Marketing, 69 61-83.

Meuter, M., Ostrom, A., Bitner, M. and Roundtree, R. (2003) The influence of technology anxiety on consumer use and experiences with self-service technologies, Journal of Business Research, 56 899-906.

Meuter, M., Ostrom, A., Roundtree, R. and Bitner, M. (2000) Self-Service Technologies: Understanding Customer Satisfaction with Technology-Based Service Encounters, Journal of Marketing, 64 50-64.

Nadkarni, S. and Gupta, R. (2007) A task baseed model of perceived website complexity, MIS Quarterly, 31 (3), pp. 501-524.

Parasuraman, A. (2000) Technology Readiness Index (TRI): A Multiple-Item Scale to Measure Readiness to Embrace New Technologies, Journal of Service Research, 2 (4), pp. 307-320.

Parasuraman, A. and Colby, C. L. (2001) Techno-Ready Marketing, How and Why your Customers Adopt Technology, The Free Press, New York.

Rogers, E. (1995) Diffusion of Innovations, Free pres, New York.

Satyanarayanan, M. (2001) Pervasive computing: vision and challenges, Personal Communications, IEEE 8(4), pp. 10 - 17.

Simon, F. and Usunier, J.-C. (2007) Cognitive, demographic, and situational determinants of service customer preference for personnel-in-contact over self-service technology, International Journal of Research in Marketing, 24 163-173.

Tsikriktsis, N. (2004) A Technology Readiness-Based Taxonomy of Customers: A Replication and Extension, Journal of Service Research, 7 (1), pp. $42-52$.

Venkatesh, V., Morris, M. G., Davis, G. B. and Davis, F. D. (2003) User Acceptance of Information Technology: Toward a Unified View, MIS Quarterly, 27 (3), pp. 425-478.

Wemmerlov, U. (1990) A taxonomy for service processes and its implications for system design, International Journal of Service Industry Management, 1 (3), pp.

Wood, R. (1986) Task Complexity: Definition of the Construct, Organizational Behavior and Human Decison Processes, 37 60-82.

Zeithaml, V. and Gilly, M. (1987) Characteristics Affecting the Acceptance of Retailing Technologies: A Comparison of elderly and Nonelderly Consumers, Journal of Retailing, 63 (1), pp. 